\title{
РАНОСРЕДЊОВЕКОВНИ НАЛАЗИ ИЗ ГОРЊЕГ БРЕГА КОД СЕНТЕ
}

\author{
Перица Шпехар \\ Универзитет у Београду, Филозофски факултет - \\ Одељење за археологију, Београд \\ Рашко Рамадански \\ Градски музеј Бечеј, Бечеј \\ \begin{tabular}{r|r} 
e-mail: perica.spehar@gmail.com & Претходно саопштење \\
Примљено: 30.4. 2021. & УДК: 904”653”(497.113) \\
Прихваћено: 9. 6. 2021. & 069.51:904(497.113)
\end{tabular}
}

\begin{abstract}
Апстракт: У археолошкој збирици Градског музеја у Сенти налази се више десетина раносредњовековних археолошких налаза, који нису публиковани на адекватан начин, већ су у досадашюој стручној литератури третирани само сумарно. На основу увида у скромну теренску документаиију и инвентарне књиге, утврђено је да су поменути налази откривени средином прошлог века у атару села Горњи Брег. Реч је два локалитета, на којима се налазе три некрополе. На локалитету Циглана, удаљеном око 1,5 км од Горњег Брега у правиу севера, откривен је 1958. године гроб из периода мађарског насељавања у Панонску низију. Друго налазиште констатовано је 1963. године приликом земьаних радова у дворишту ватрогасне касарне и суседне окућние у Горьем Брегу. Током археолошких ископавања мањег обима ту је констатовано пет гробних целина. Једна сахрана припада позноаварском периоду, док се преостале четири, које су биле удаљене неколико десетина метара, могу определити у период формираға мађарске државе. Рад се бави овим, до сада запостављеним налазима, који пружају важне податке за проучавање раносредњовековног раздобља на простору јужне Паноније.
\end{abstract}

Кључне речи: јужна Панонија, некрополе, раносредњовековни период, позноаварски период, период досељавања Мађара

\section{Увод}

Село Горњи Брег (мађ. Felsőhegy) налази се око пет километара западно од Сенте (сл. 1/А). Највећим делом је смештено на узвишењу - лесној греди, оријентисаној у правцу север-југ, чија се надморска висина креће између 93 и 111 м. Ова греда доминира окружењем, односно Бачком (Телечком) заравни, чија висина у подножју села Горњи Брег износи око 81 м (Јокић 2004, 21). Археолошки локалитети Циглана и Ватрогасна касарна, који су тема рада, заправо се налазе на северној и јужној падини лесне греде, односно на контактним зонама различитих геоморфолошких целина. 


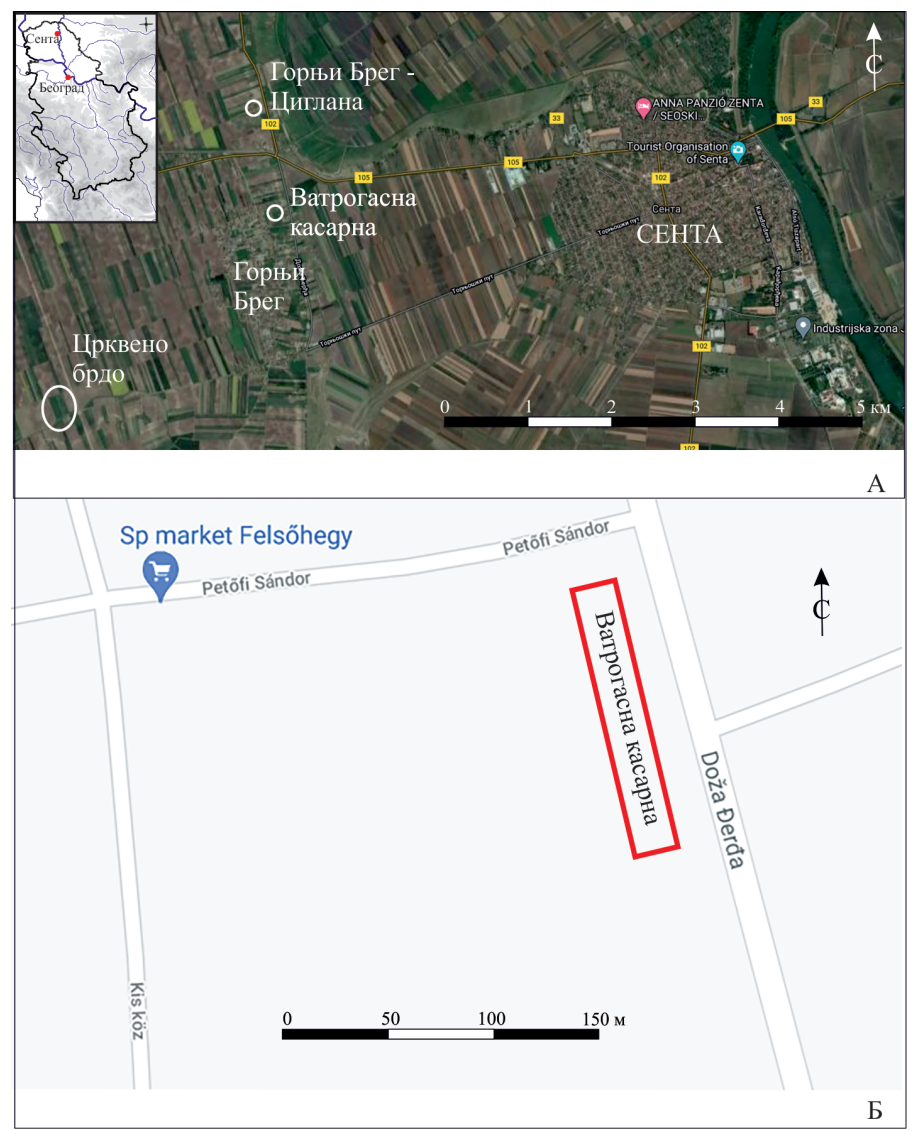

Сл. 1. А - Положај локалитета у атару Горњег Брега (нацртао П. Шпехар на подлози преузетој ca Google maps); Б - Положај Ватрогасне касарне у Горњем Брегу (нацртао П. Шпехар на подлози преузетој са Google maps)

Fig. 1. A - Position of the sites in the area of Gornji Breg (drawn by P. Špehar on the basis of Google maps); Б - Position of the Vatrogasna Kasarna in Gornji Breg (drawn by P. Špehar on the basis of Google maps)

Локалитет Циглана налази се око 1,5 км северно од Горњег Брега. У марту 1958. године на највишој тачки у западном профилу позајмишта земље пронађен је гроб. Уследила су заштитна археолошка ископавања, којима је руководио К. Хађмаш, препаратор Народног музеја у Сенти. Расположиви подаци из документације, који нису садржали основу гроба, указују да је том приликом сакупљен и антрополошки материјал, који нажалост није сачуван. Гробни инвентар откривен том приликом данас се налази у археолошкој збирци Градског музеја Сента. ${ }^{1}$

\footnotetext{
${ }^{1}$ Откривени предмети носе инв. бр. А835-А838.
} 
Свега неколико година касније, у јулу 1963, у источном делу села Горњи Брег, приликом земљаних радова у двориштима ватрогасне касарне и суседне окућнице, откривено је неколико гробова. Налазиште је смештено на углу данашњих улица Петефи Шандор, која се пружа приближно у правцу исток-запад, и Дожа Ђерђа, која је оријентисана приближно по оси север-југ (сл. 1/Б). Зона у којој су откривени гробови се својом дужом страном пружа готово паралелно са Улицом Дожа Ђерђа, са њене западне стране. Приликом радова констатовано је да је један од гробова био издвојен и удаљен неколико десетина метара. На основу тога, као и карактера налаза из издвојеног гроба, закључено је да су овде заправо откривене две некрополе, позноаварска некропола и некропола из периода мађарског досељавања. Расположива рукописна документација оскудно описује најмање два гроба са прилозима, као и остатке коња, а наводи се чак и налаз новца. ${ }^{2}$ Ипак, није било могуће утврдити за који од гробова се везује коњска сахрана. Налази откривени том приликом, изузимајући новац коме се у међувремену губи траг, налазе се у археолошкој збирци Музеја града у Сенти, док остеолошки материјал, као и у случају локалитета Циглана, није сачуван.

У досадашњој стручној и научној литератури једино је Л. Секереш поменуо локалитет Ватрогасна касарна у прегледу археолошких налазишта Сенте и околине (Szekeres 1971, 92), али са погрешним датумом ископавања ${ }^{3}$ и без описа материјала или фотографија. Стручној јавности су први пут представљени ови налази и скренута пажња на важност материјала у излагању Р. Рамаданског на Секцији за средњи век Српског археолошког друштва у Бечеју 2017. године. ${ }^{4}$

\section{Анализа археолошког материјала}

Сакупљени археолошки материјал разврстан је по целинама првенствено на основу инвентарне књиге, али и помоћу података из оскудне теренске документације. Стога су информације о положају гробног места, његовом изгледу, оријентацији, дубини укопа, као и полу преминулих неуједначени. Током самих ископавања нису начињени ситуациони план некрополе, као ни основе гробова. Такође, откривене гробне целине нису нумерисане, већ су гробови своје бројне ознаке добили од аутора̂ овог текста. Иако до нас није доспео откривени новац, археолошки материјал је могуће, на основу добро датованих аналогија, хронолошки поуздано определити.

\footnotetext{
2 Белешке је сачинио П. Катона, документариста Народног музеја у Сенти.

${ }^{3}$ Наводи се 1969. година, о којој нема помена у расположивој документацији.

${ }^{4}$ Р. Рамадански је том приликом изложио реферат под називом Необјављени налази са гробља IX-X века у Горњем Брегу код Сенте.
} 


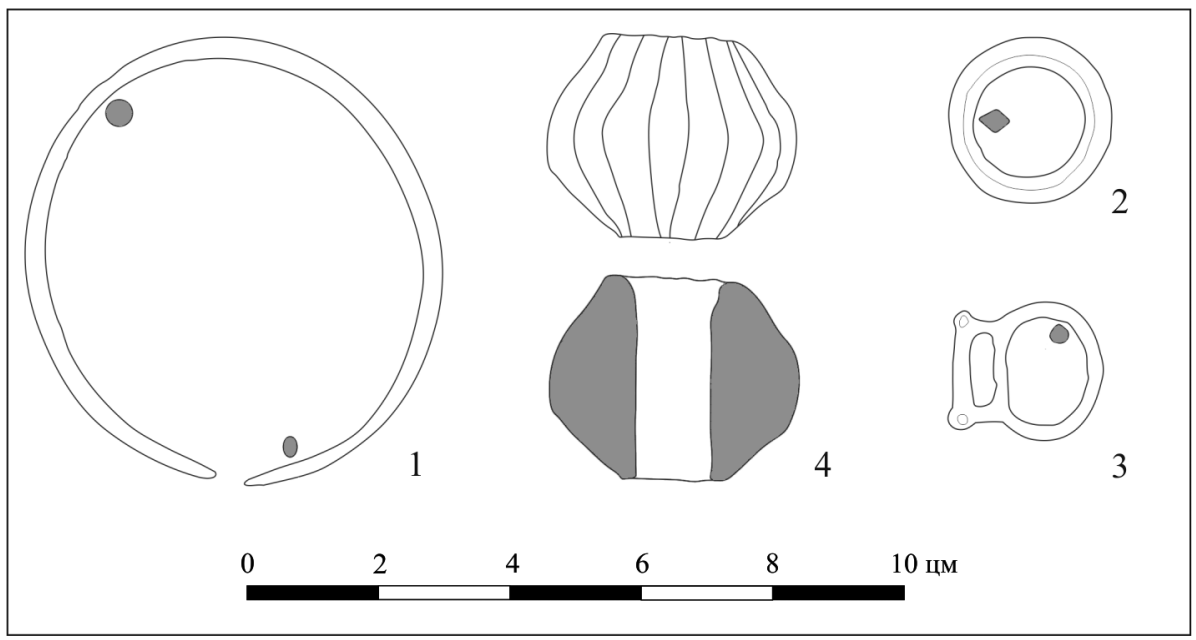

Сл. 2. Горњи Брег - Циглана, Гроб 1 (нацртао Д. Симић)

Fig. 2. Gornji Breg - Ciglana, Grave 1 (drawn by D. Simić)

\section{Локалитет Горњи Брег - Циглана}

\section{Гроб 1}

Гроб жене. Скелет се налазио на релативној дубини од 0,35 м. Из гроба потичу следећи налази:

1. Пуноливена сребрна наруквица отвореног типа, неправилног кружног облика. На средишњем делу има кружни пресек, а на крајевима овални (сл. $2 / 1$; сл. 7/B/1).

Највећи пречник 6,8 цм.

Инв. бр. А 835

2. Пуноливени бронзани прстен кружног облика и ромбоидног пресека (сл. 2/2).

Спољашњи пречник 2,5 цм, унутрашњи пречник 1,2 цм.

Инв. бр. А 836

3. Мала бронзана копча типа лира. На предњем крају, налазе се остаци два закивка којима се причвршћивала за каиш. Недостаје јој трн (сл. 2/3).

Димензије 2,3 х 2,1 цм.

Инв. бр. А 838

4. Биконични керамички пршљенак црвено-окер боје, чија је спољашњост украшена вертикално изведеним урезима (сл. 2/4).

Висина 3,1 цм, пречник врха 2 цм, пречник дна 1,7 цм, пречник средишњег дела 3,8 цм, пречник отвора 1,2-1,4 цм.

Инв. бр. А 837 
Налаз који пружа више података за прецизније хронолошко опредељење представља копча типа лира (сл. 2/3). Реч је о налазу означеном као тип А према типологији Л. Ревеша (Révész 1987, 270, Abb. 6.2), опредељеном u 10-11. век, односно сврстаном у тип 2d типологије Е. Гала, који се датује у сам крај 10. века (Gáll 2013, Т. 317, Т. 334). Овакве копче чиниле су део коњске опреме, о чему сведочи налаз са локалитета Ходмезевашархељи-Нађисигет (Hódmezővásárhely-Nagysziget), откривен на лобањи коња (Révész 1987, 260, Abb. 2-3), али и део појаса. На то упућује географски најближа аналогија из Дорослова (Станојев 1989, 45, кат. бр. 226), као и идентични налази познати са читавог простора Карпатске котлине (Bálint 1991, 90, Taf. XXX/1; Fodor 1996a, 117, Fig. 10; Gáll 2013, 118, Cat. No. 21/1, T. 38/21/1), који су откривени у пределу карлице. Слично је и са сребрном наруквицом (сл. $2 / 1$; сл. 7/B/1) која припада типу 2а типологије Е. Гала, а која је опредељена у прву половину 11. века (Gáll 2013, 677, T. 311, 330, 333, 334). На основу предоченог можемо рећи да је у питању гроб женске особе из вишег сталежа, сахрањене у првој половини 11. века.

\section{Локалитет Горњи Брег - Ватрогасна касарна (позноаварска некропола)}

\section{Гроб 1}

Гроб мушкарца у испруженом положају, оријентисан у правцу запад-исток. Скелет се налазио на релативној дубини од 1,5 м. У пределу груди су се на костима видели трагови зелене оксидације, који указују на положај откривених налаза. Из гроба потичу следећи налази:

1. Бронзана копча са оковом, чија је алка у облику трапезоида, квадратног пресека. Са задње стране алке налази се оков неправилног облика, који има два наспрамно постављена проширења у облику волуте, док је задњи крај полукружно изведен. Копча има кратак трн (сл. 3/1).

Димензије: 4,7 х 2,7 цм.

2. Два фрагмента бронзаног ливеног језичка неправилног четвороугаоног облика, чије се бочне ивице постепено благо сужавају. Предњи крај је шупаљ како би се у њега убацио каиш. Кожа и језичак су били додатно учвршћени мањим закивком кружног облика, о чему сведочи мали кружни отвор на средини задње ивице језичка. Предњи део језичка обликован је полукружно. Површина је украшена флоралним орнаментом, највероватније мотивом винове лозе (сл. 3/2).

Димензије: 1,7 x 1,5 цм; 2,2 x 1,1 цм. 


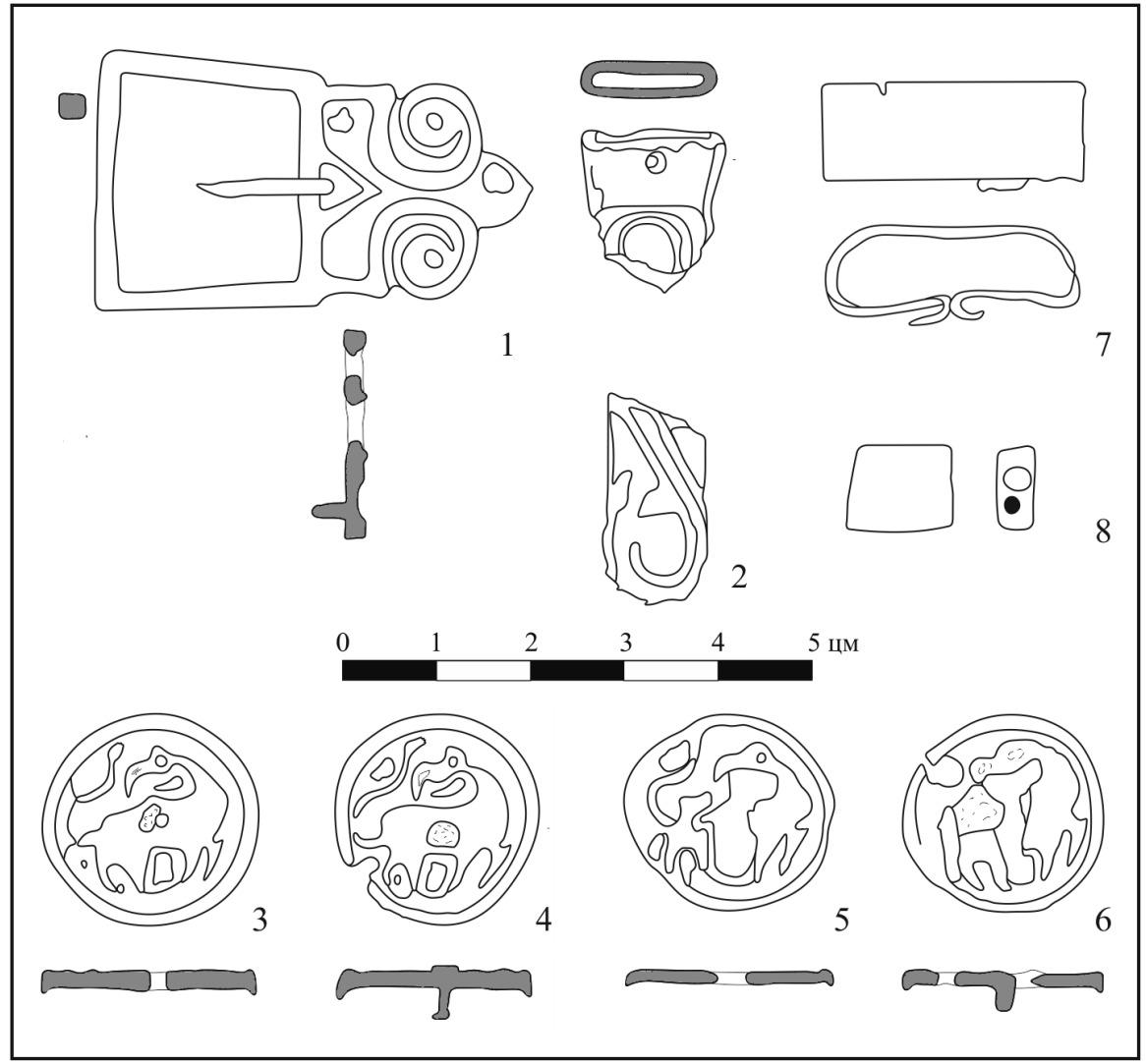

Сл. 3. Горњи Брег - Ватрогасна касарна (позноаварска некропола), Гроб 1 (нацртао Д. Симић)

Fig. 3. Gornji Breg - Vatrogasna Kasarna (Late Avar necropolis): A - Grave 1 (drawn by D. Simić)

3. Бронзани појасни оков кружног облика израђен техником ливења са проламањем. Украшен је профилном представом грифона, чија глава гледа уназад ка подигнутом репу. Са задње стране, на средини, налази се вертикално постављен трн, којим се апликација причвршћивала за појас (сл. 3/3). Пречник: 2,3 цм.

4. Исто као претходни налаз (сл. 3/4).

Пречник: 2,2 цм.

5. Исто као претходни налаз (сл. 3/5)

Пречник: 2,1 цм.

6 Исто као претходни налаз (сл. 3/6).

Пречник: 2,2 цм. 
7. Гајка појаса начињена од савијеног бронзаног лима, чији су крајеви лучно повијени ка споља (сл. 3/7).

Димензије: 2,8 × 1 цм.

8. Перла у облику неправилног квадрата, правоугаоног пресека, начињена од зеленог стакла. На краћим бочним странама се уочавају две кружне перфорације: већа у потпуности пролази кроз перлу, док је мања избушена до средине (сл. 3/8; сл. 7/A/1).

Димензије: 1,2 х 0,9 х 0,4 цм; пречник веће перфорације: 0,3 цм; пречник мање перфорације: 0,15 цм.

Налази који потичу из овог гроба могу се везати за позноаварски период, ${ }^{5}$ током кога се јављају појасеви украшени са четири кружна окова, што је констатовано у гробу 1246 на некрополи Тисафиред I (Tiszafüred I) (Garam 1987, T. 24/unten). Према општеприхваћеној серијацији Ј. Забојника копча (сл. 3/1) припада типу 127 , који се датује у прелаз између фаза SS II (720-750) i SS III (750-780) (Zábojník 1991, 239, Taf. 26/127). Иако је појасни језичак поприлично оштећен (сл. 3/2), могуће је идентификовати га као серијацијски тип 105, који је опредељен у фазу SS II (Zábojník 1991, 238-239, Taf. 23/105). Истој фази припадају и кружни окови (сл. 3/4-7) опредељени као тип 204 (Zábojník 1991, 238, Taf. 36/204). Појасну гајку (сл. 3/3) није нажалост могуће тако прецизно датовати, мада је сличан примерак откривен на некрополи у Баваништу (Ђорђевић 2010: 136, T. CL/3), где је једна гробна целина поуздано опредељена у другу четвртину 8. века (Бугарски 2014, 605). Стога можемо претпоставити да је до сахране дошло највероватније средином или у трећој четвртини 8. века.

\section{Локалитет Горњи Брег - Ватрогасна касарна (некропола из периода мађарског досељавања)}

\section{Гроб 1}

Гроб скелетно сахрањеног мушкарца, из кога потичу следећи налази:

1. Фрагаментована гвоздена узенгија трапезоидног облика. Оштећена петља је имала хоризонтално постављени отвор правоугаоног облика. Доњи део узенгије, на који се ослањала нога, поломљен је (сл. 4/A/1). Очувана висина: 13,6 цм; највећа очувана ширина: 11,8 цм.

2. Исто као претходни налаз (сл. 4/A/2).

Очувана висина: 10,8 цм.

\footnotetext{
5 Захваљујемо др Ивану Бугарском, вишем научном сараднику Археолошког института у Београду, на помоћи приликом хронолошког опредељења налаза из овог гроба.
} 


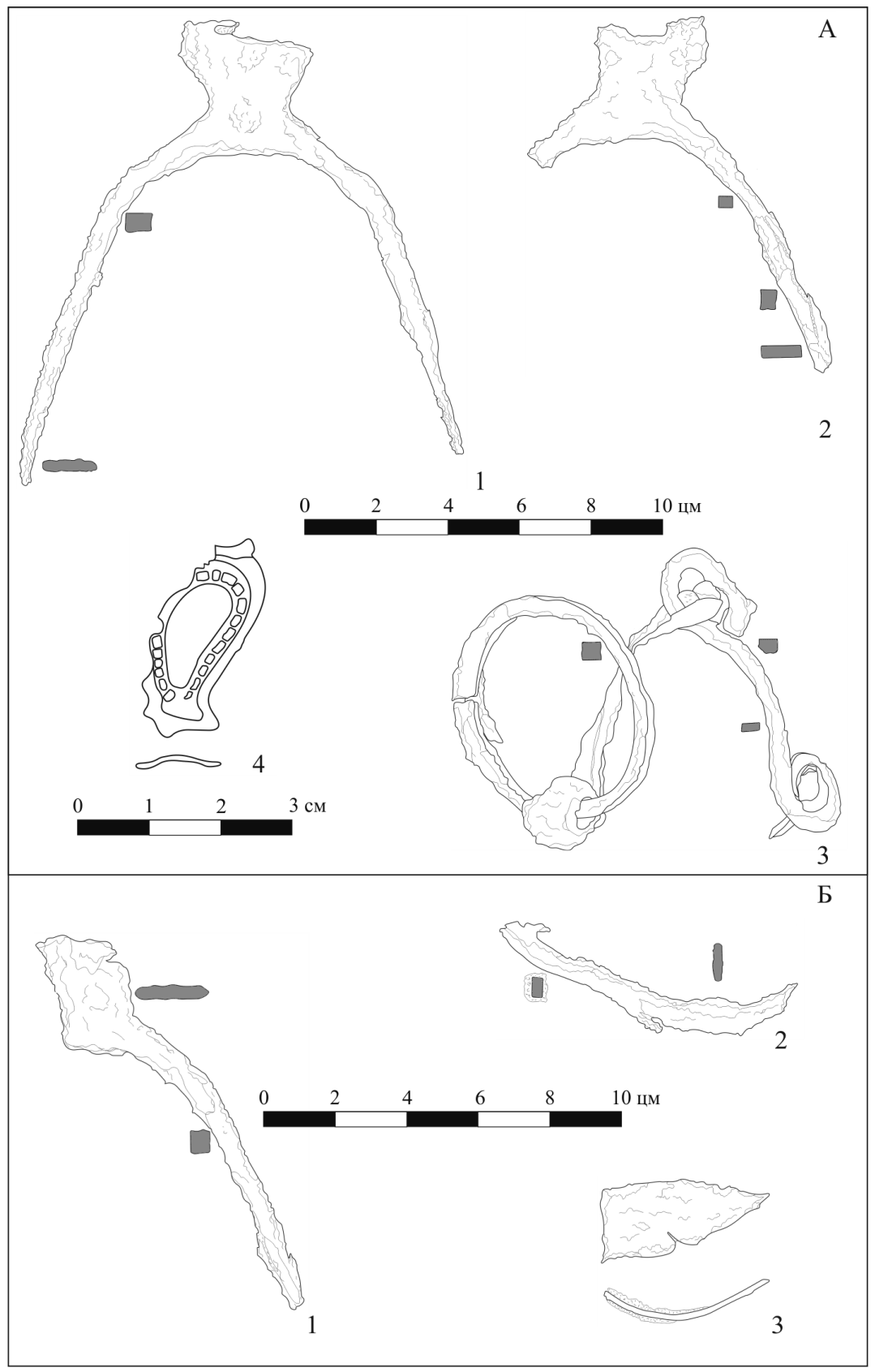

Сл. 4. Горњи Брег - Ватрогасна касарна (некропола из периода насељавања Мађара): А - Гроб 1 (нацртао Д. Симић); Б - Гроб 2 (нацртао Д. Симић)

Fig. 4. Gornji Breg - Vatrogasna Kasarna (necropolis from the period of the Magyar settlement): A - Grave 1 (drawn by D. Simić); Б - Grave 2 (drawn by D. Simić) 
3. Кородиране, делимично очуване гвоздене жвале. Састоје се од две међусобно спојене шипке правоугаоног пресека, на крајевима савијене у облику кружне петље, док су у средишњем делу благо лучно повијене. Кроз крај једне од шипки провучена је кружна алка квадратног пресека, а друга алка недостаје (сл. 4/A/3).

Дужина шипки: 8,7 и 8,8 цм; пречник алке: 6,3 цм.

4. Оштећена издужена апликација у облику лире од позлаћеног сребрног лима, од које је очувана само једна половина. На средини апликације се налази капљичасти украс, око кога су кружни мотиви (сл. 4/A/4).

Димензије: 3,7 цм х 1,4 цм.

Налази коњаничке опреме откривени у овом гробу везују се за период досељавања Мађара на простор јужне Паноније. Пар трапезоидних узенгија (сл. 4/A/1-2), због степена оштећености петље, није могуће сврстати у неку од утврђених варијанти које нуде прецизније датовање, па се морамо задовољити оквирним хронолошким опредељењем у 10. век, односно најкасније у прве деценије 11. века (Kovács 1986, 204-224; Gáll 2015, fig. 17-18). Ипак, неопходно је напоменути да се овакве узенгије ретко срећу на територији Војводине (Шпехар и Стругар Бевц 2016, 95, сл. 7.15). Жвале (сл. 4/A/1-2) припадају најједноставнијем типу раномађарских налаза ове врсте (Gáll 2013, 767, kép. 256), какви су нам познати из Футога (Станојев 1989, кат. бр. 679-680) или Батајнице (Шпехар и Стругар Бевц 2016, 92, сл. 7.12). На крају, пажњу треба скренути и на фрагментовану сребрну позлаћену апликацију у облику лире (сл. 4/A/3), за коју нисмо нашли директну аналогију, мада сличан налаз, опредељен у 10. век, потиче са некрополе Кенезле-Фазекасуг (Kenézlö-Fazekaszug) II (Révész 1996,156, fig. 13). На основу предочених налаза можемо претпоставити да се ради о ратничкој сахрани. Присуство коњске опреме у раномађарским гробовима тесно је повезано са улогом коња у војним походима, што је као последицу имало праксу парцијалног сахрањивања коња са њиховим власницима. Овакав погребни обред био је резервисан за најистакнутије чланове заједнице, пре свега ратнике током 10. и прве трећине 11. века (Тактика: const. 18; Bálint 1969; Révész and Nepper 1996, 39; Kürti, 1997, 127-136; Gáll 2010, 283-294; Türk 2014, 145-146; Шпехар и Стругар Бевц 2016, 70).

\section{Гроб 2}

Гроб скелетно сахрањеног мушкарца, у коме су откривени следећи налази:

1. Фрагмент крушколике узенгије (сл. 4/Б/1).

Очувана висина: 10,8 цм. 
2. Два фрагмента ослонца за ногу узенгије који се не спајају међусобно (сл. 4/Б/2-3).

Димензије: 8,2 × 2 цм, 4,1 х 2 цм.

Откривени фрагменти највероватније чине пар узенгија, од којих је једна била крушколиког облика, док другу услед степена оштећености није могуће типолошки определити. Стога се, као и у претходном случају, морамо задовољити ширим хронолошким оквиром, који се везује за 10. век и прве деценије 11. века (Gáll 2015, fig. 17-18). Није могуће утврдити ни директне аналогије, па ћемо само навести да је овај тип узенгија доста чест на налазиштима у Војводини (Станојев 1989, кат. бр. 16-17, 74-75, 341-342, 680, 701-702; Kovács 1992, kép. 10/132, 12/2; Шпехар и Стругар Бевц 2016, 94-95, сл. 7.13, 7.14, T. VIII/9). Попут претходног гроба и овај се може окарактерисати као сахрана из друге половине 10. или прве половине 11. века.

\section{Гроб 3}

Гроб скелетно сахрањене жене, у коме су откривени следећи налази:

1. Бронзана наруквица отвореног типа, неправилног кружног облика, начињена преплитањем четвороструко преплетене жице. На крајевима се налазе две овално изведене петље, од којих је једна лучно повијена. Наруквица се затварала убацивањем једне петље на другу. Крај наруквице на коме се налази повијена петља изведен је вертикално постављеним намотајима (сл. 5/1). Највећи пречник: 7,7 цм.

2. Исто као претходни налаз. Делимично оштећена (сл. 5/2). Највећи пречник: 7,7 цм.

Овакве наруквице, које се углавном срећу у пару у гробовима, Е. Гал сврстава у тип За и опредељује у прву половину 11. века (Gáll 2013, 677 , Т. 311, 334). Познати су релативно бројни слични налази наруквица на територији Војводине, при чему део њих нема крај који је изведен од вертикално постављених намотаја попут наших примерака (Станојев 1989, кат. бр. 35, 136, 490, 661, 694, 708-709). Овом приликом поменућемо да се истоветан примерак среће на локалитету Фенлак (Fönlak) у Румунији (Gáll 2013, 110-111, Cat. No. 4.4, T. 25/2). На основу расположиве грађе можемо закључити да је сахрана спроведена током прве половине 11. века.

\section{Гроб 4}

Гроб скелетно сахрањене жене, из кога потичу следећи налази:

1. Једноставна бронзана каричица отвореног типа од жице кружног пресека (сл. 6/1).

Пречник: 2,3 цм. 


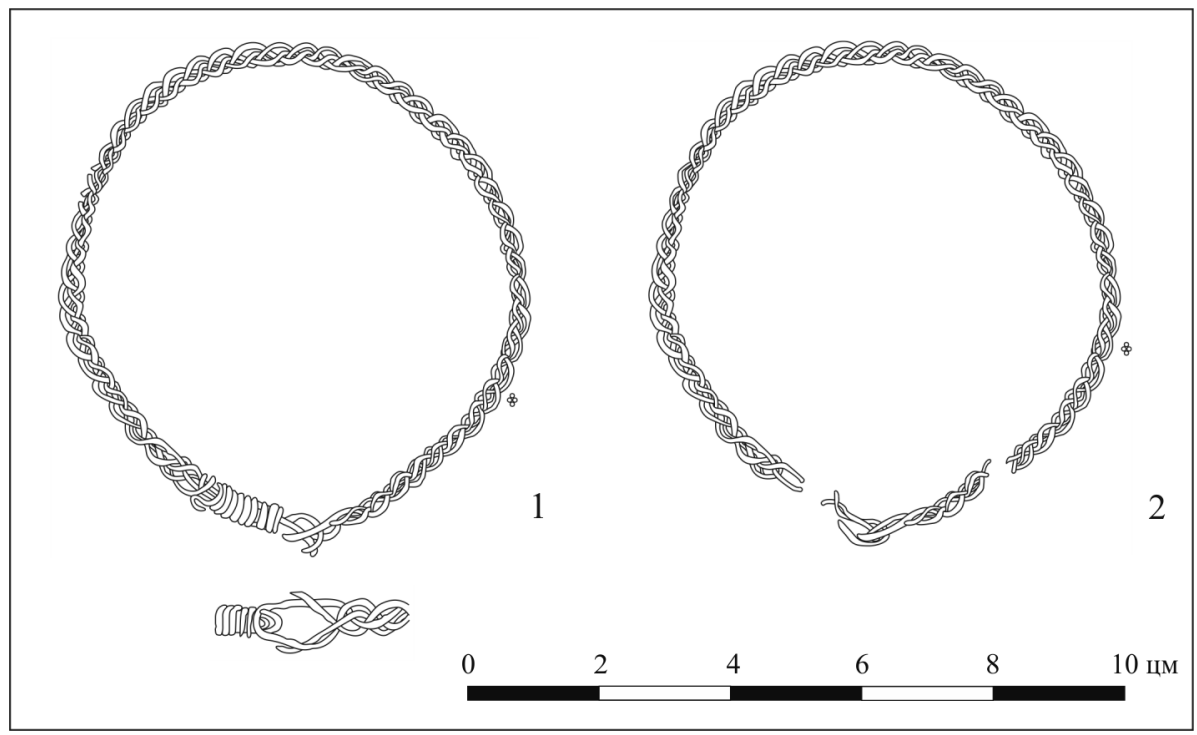

Сл. 5. Горњи Брег - Ватрогасна касарна (некропола из периода насељавања Мађара), Гроб 3 (нацртао Д. Симић)

Fig. 5. Gornji Breg - Vatrogasna Kasarna (necropolis from the period of the Magyar settlement), Grave 3 (drawn by D. Simić)

2. Исто као претходни налаз. Начињен од тање жице (сл. 6/2).

Пречник: 2,3 цм.

3. Двојна перла од тамножутог стакла (сл. 6/3; сл. 7/A/2).

Висина: 1,1 цм, пречник: 0,6 цм.

4. Тројна перла од сивоплавог стакла, делимично оштећена (сл. 6/4; сл. 7/A/3).

Висина: 1,3 цм, пречник: 0,7 цм.

5. Четворострука перла од светлог, јаркожутог стакла (сл. 6/5; сл. 7/А/4). Висина: 1,2 цм, пречник: 0,4 цм.

6. Пуноливено бронзано дугме печуркастог облика, са кружном петљом на доњем делу. Глава је са спољашње стране украшена са осам паралелних пластичних ребара (сл. 6/6).

Висина: 1,9 цм, пречник петље: 0,6 цм, пречник главе: 0,8 цм.

7. Бронзани ливени лоптасти прапорац са квадратном петљом за качење, на којој се налази кружни отвор. Са доње стране налази се крстолики отвор. Сачувана је само једна половина прапорца, док је петља делимично оштећена (сл. 6/7).

Висина: 2 цм, пречник: 1,4 цм. 


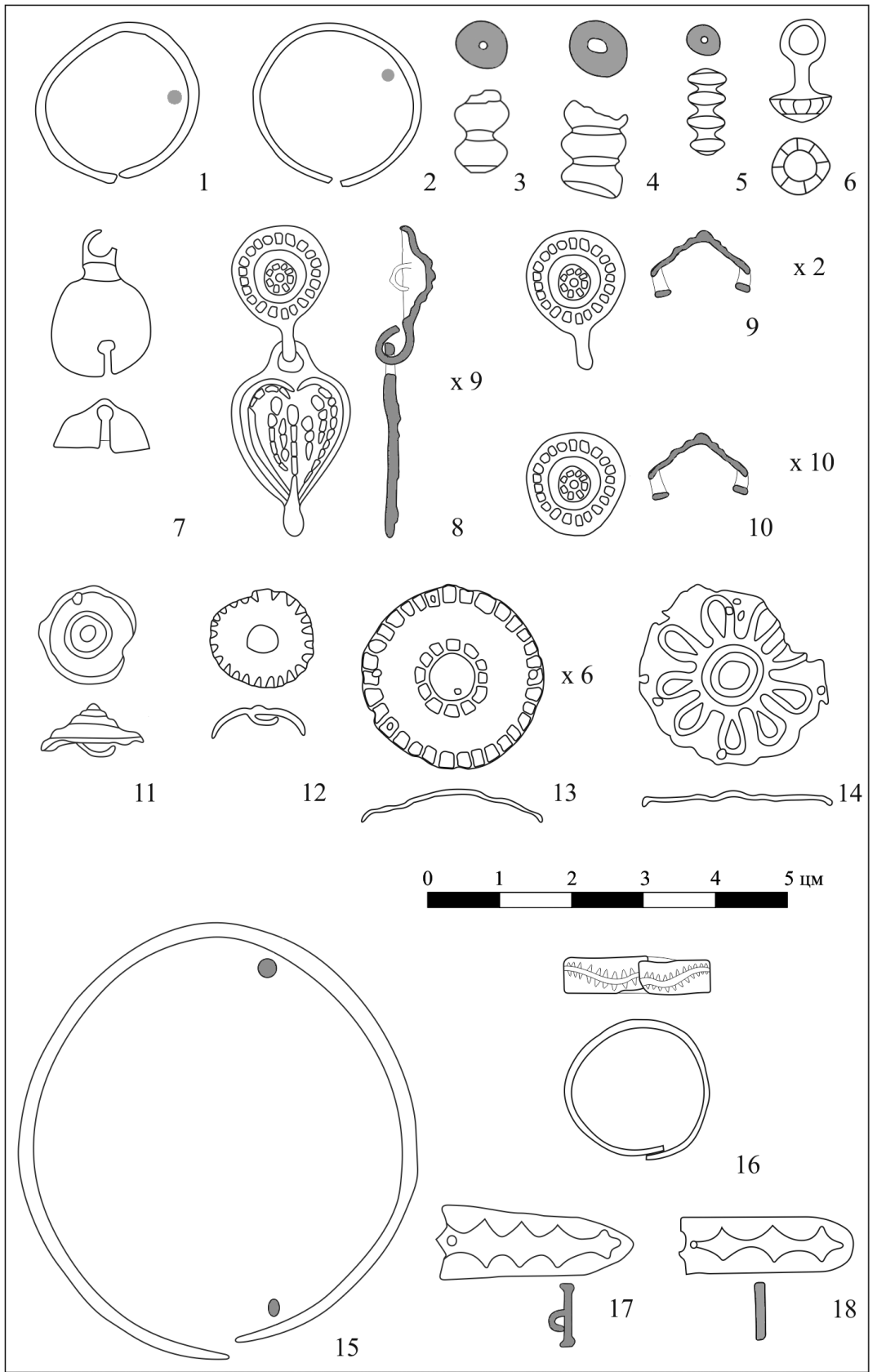

Сл. 6. Горњи Брег - Ватрогасна касарна (некропола из периода насељавања Мађара), Гроб 4 (нацртао Д. Симић)

Fig. 6. Gornji Breg - Vatrogasna Kasarna (necropolis from the period of the Magyar settlement), Grave 4 (drawn by D. Simić) 
8. Дводелна апликација начињена од бронзаног лима, чији је горњи део кружног, а доњи срцоликог облика. Ова два дела спојена су помоћу кукице која се налази на горњем кружном делу, провучена кроз кружни отвор на горњој страни доњег дела апликације. На горњем делу апликације, са његове задње стране, налазе се и две управно постављене кружне петље, кроз које се провлачила трака или нит. Површина горњег дела апликације украшена је кружним мотивима распоређеним дуж спољашње ивице, као и низом кружних мотива распоређених око централног мотива у средишњем делу. Срцолики део је украшен кружним и овалним мотивима који прате спољашње ивице, док се у средишњем делу налази пет вертикалних низова изведених на исти начин (сл. 6/8).

Дужина: 4,3 цм; пречник кружног дела: 1,3 цм; дужина срцоликог дела: 2,2 цм. 9. Исто као претходни налаз.

Дужина: 4,3 цм; пречник кружног дела: 1,3 цм; дужина срцоликог дела: 2,2 цм. 10. Исто као претходни налаз.

Дужина: 4,3 цм; пречник кружног дела: 1,3 цм; дужина срцоликог дела: 2,2 цм. 11. Исто као претходни налаз.

Дужина: 4,3 цм; пречник кружног дела: 1,3 цм; дужина срцоликог дела: 2,2 цм. 12. Исто као претходни налаз. Дужина: 4,3 цм; пречник кружног дела: 1,3 цм; дужина срцоликог дела: 2,2 цм. 13. Исто као претходни налаз. Дужина: 4,3 цм; пречник кружног дела: 1,3 цм; дужина срцоликог дела: 2,2 цм. 14. Исто као претходни налаз.

Дужина: 4,3 цм; пречник кружног дела: 1,3 цм; дужина срцоликог дела: 2,2 цм. 15. Исто као претходни налаз. Дужина: 4,3 цм; пречник кружног дела: 1,3 цм; дужина срцоликог дела: 2,2 цм. 16. Исто као претходни налаз. Очуван само горњи, кружни део (сл. 6/9). Пречник: 1,3 цм.

17. Исто као претходни налаз.

Пречник: 1,3 цм.

18. Кружна апликација начињена од бронзаног лима, чија је површина украшена кружним мотивима распоређеним дуж спољашње ивице, као и низом кружних мотива, распоређених око централног кружног мотива. Са задње стране се налазе две усправно постављене кружне петље, кроз који се провлачила трака или нит (сл. 6/10).

Пречник: 1,3 цм. 
19. Исто као претходни налаз. Пречник: 1,3 цм

20. Исто као претходни налаз. Пречник: 1,3 цм.

21. Исто као претходни налаз. Пречник: 1,3 цм.

22. Исто као претходни налаз. Пречник: 1,3 цм.

23. Исто као претходни налаз. Пречник: 1,3 цм.

24. Исто као претходни налаз. Пречник: 1,3 цм.

25. Исто као претходни налаз. Пречник: 1,3 цм.

26. Исто као претходни налаз. Пречник: 1,3 цм.

27. Исто као претходни налаз. Пречник: 1,3 цм.

28. Кружна, испупчена апликација начињена од бронзаног лима, украшена са два концентрично распоређена круга у средишњем делу, док трећи круг прати њену ивицу. Са задње стране налази се једна управно постављена кружна петља (сл. 6/11).

Пречник: 1,3 цм.

29. Кружна бронзана апликација начињена од лима, дуж чије се спољашње ивице пружа низ троугаоних орнамената. Са унутрашње стране налази се вертикално постављена петља кружног облика (сл. 6/12).

Пречник: 1,9 цм.

30. Кружна апликација начињена од сребрног лима. Украшена је низом неједнаких квадрата неправилног облика дуж спољашње ивице, док се истоветан низ налази у централном делу. На апликацији се види пет малих кружних перфорација (сл. 6/13; сл. 7/Б/1).

Пречник: 2,5 цм.

31. Исто као претходни налаз. Фрагментовано. Пречник: 2,5 цм.

32. Исто као претходни налаз. Фрагментовано. Пречник: 2,5 цм. 


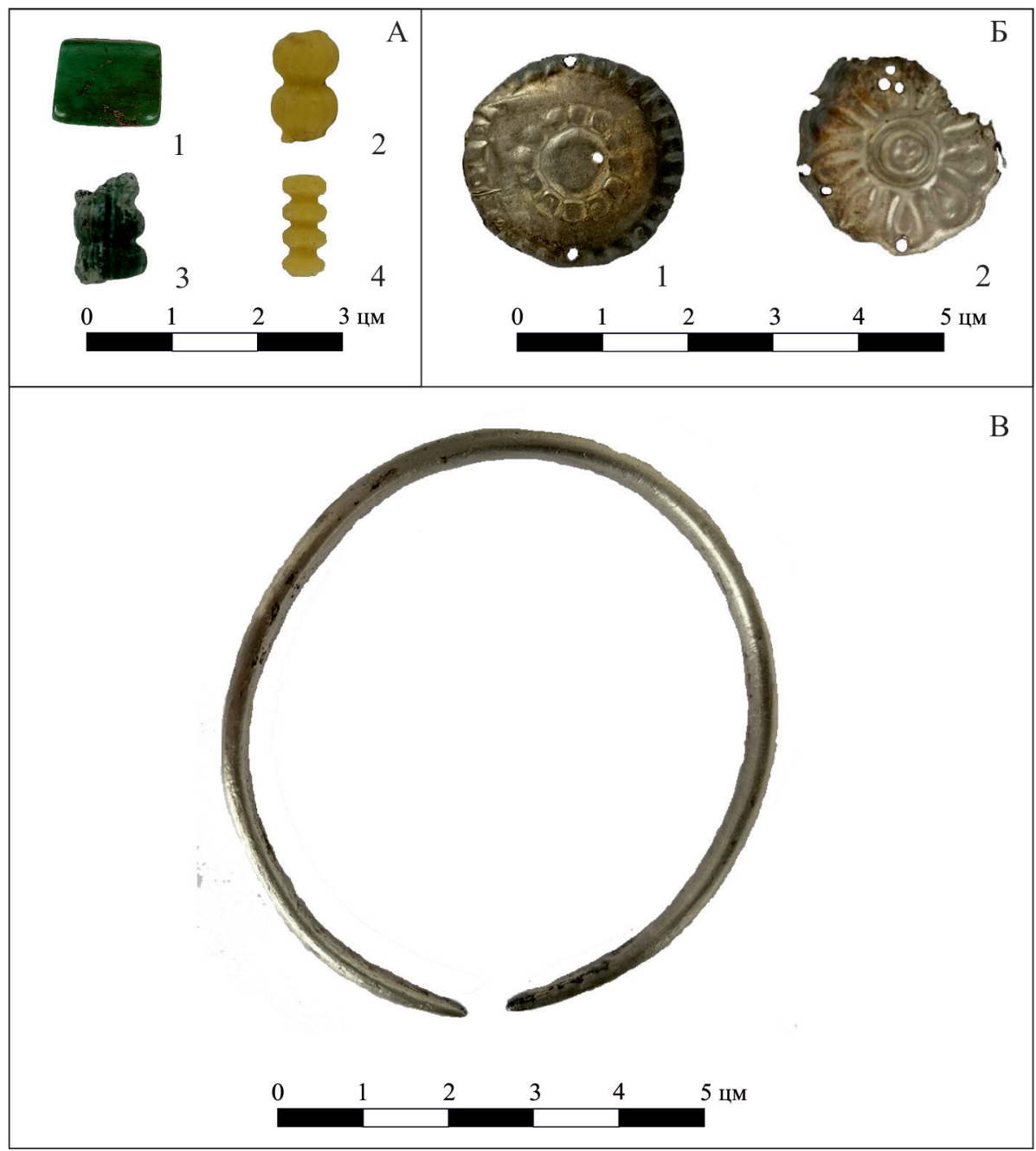

Сл. 7. А - стаклене перле (фото П. Шпехар); Б - сребрне апликације (фото. П. Шпехар); В - сребрна наруквица (фото. П. Шпехар)

Fig. 7. A - glass beads (photo by P. Špehar); Б - silver applications (photo by P. Špehar); B - silver bracelet (photo by P. Špehar)

33. Исто као претходни налаз. Оштећено.

Пречник: 2,6 цм

34. Исто као претходни налаз. Фрагментовано.

Пречник: 2,5 цм.

35. Исто као претходни налаз. Оштећено.

Пречник: 2,6 цм. 
36. Оштећена кружна апликација начињена од сребрног лима. Украшена је представом деветолатичног цвета. На апликацији се види осам малих кружних перфорација (сл. 6/14; сл. 7/Б/2).

Пречник: 2,6 цм.

37. Бронзана пуноливена наруквица отвореног типа, неправилног кружног облика. На централном делу има кружни пресек, а на крајевима овални (сл. 6/15). Највећи пречник: 6,1 цм.

38. Тракасти прстен отвореног типа, начињен од савијеног бронзаног лима. Површина је читавом дужином украшена са две паралелне валовнице, дуж којих се, са њихове спољашње стране, налазе паралелни управно постављени урези (сл. 6/16).

Пречник: 2 цм, ширина траке: 0,5 цм.

39. Мањи бронзани језичак полигоналног облика, чији се предњи крај завршава у облику петоугла заобљених ивица, док му је задњи крај изведен у виду изломљене линије. Површина је украшена са две валовнице које прате дужу ивицу и спајају се у предњем делу. На доњој страни налазе се два вертикално постављена мања кружна отвора за учвршћивање за каиш (сл. 6/17). Димензије: 2,7 х 1,1 цм.

40. Слично као претходни налаз. Задњи део је оштећен (сл. 6/18). Димензије: 2,7 x 1,1 цм.

Из гроба 4 потиче највећи број налаза. Преглед започињемо са две једноставне каричице начињене од тање жице (сл. 6/1-2). Ова врста налаза, која је могла бити начињена од сребра или бронзе, у стручној литератури се тумачи као наушница или као украс на плетеници, коју су током раномађарског периода носили подједнако и мушкарци и жене. Примерци откривени у Горњем Брегу припадају првом типу каричица типологије Е. Гала, која се јавља у две варијанте у зависности од тога да ли се крајеви додирују или не (Giesler 1981, 88-91, Т. 3/13; Gáll 2013, 664, 882-883, kép. 194; Шпехар и Стругар Бевц 2016, 80).

У гробу 4 у Горњем Брегу део инвентара је чинила и мања огрлица, која се састојала од три стаклене перле (сл. 6/3-5; сл. 7/A/2-4). Слични налази познати су са локалитета Серег-Хомокбања (Szöreg-Homokbánya) из гроба 28 (Bálint 1991, 88, Taf. XXVIII/6-22), или са локалитета Саболч (Szabolcs) из гроба 222 (Kovács 1994, 51-54, Abb. 14). Истоветне двоструке и троструке жуте перле констатоване су на налазишту Батајница - Велика хумка у гробу 37 (Шпехар и Стругар Бевц 2016, 36, T. VI, XVI). Огрлице начињене од стаклених перли представљају релативно чест гробни инвентар 
на некрополама из периода мађарског досељавања, при чему се као специфичност јављају полихромне перле украшене белим тачкама (Szilágyi 1995; Szilágyi, Nagy-Balogh, Solymos 1995), каквих нема у Горњем Брегу. Из гроба 4 потиче и пуноливено дугме (сл. 6/6), које је осим за закопчавање горњег дела одеће веома често коришћено као украс за траку на глави или привезак на огрлици током раносредњовековног периода (Demo 2009, 132-133; Шпехар и Стругар Бевц 2016, 78), што је како се чини и овде био случај. Слични примерци потичу са бројних локалитета у Војводини (Станојев 1989, кат. бр. 14, 128, 131, 230, 351-356, 657-659; Шпехар и Стругар Бевц 2016, 79), као и са налазишта у Мађарској и Румунији (Bálint 1991, 38-42, Т. V/6; Nepper 1996, 254, fig. 25; Gáll 2013, 231, T. 103/7/24-30, T. 224/19). Што се тиче прапораца (сл. 6/7), они су тумачени као део коњске опреме, али су могли имати и функцију амулета (Јовановић 1996, 83-85; Шпехар и Стругар Бевц 2016, 83). Такође су могли бити и део огрлице, о чему сведоче налази са локалитета Вуковар - Лијева Бара из гроба 115 (Demo 2009, 236-237), односно са локалитета Саболч (Szabolcs) из гроба 341 (Kovács 1994, 61, 75-76, Abb. 17/270/114, Abb. 23/2), што је верујемо и овде био случај.

Следећу врсту налаза чини 11 двоструких бронзаних апликација (сл. 6/8-9), од којих је девет очувано у целини, док је од две остао очуван само горњи део. Ова врста налаза представља уобичајен инвентар на некрополама из периода мађарског досељавања у Панонску низију (Hampel 1904, 123, 138, 147), и опредељују се у период 10-11. века (Demo 1983, 271). Поменуте апликације се првенствено јављају као део женске одеће, али се могу срести и у гробовима у којима су сахрањени мушкарци (Bálint 1991, 66-71, Taf. XX). Према типологији Ч. Балинта, налази попут наших су сврстани у групу Іа, која је првенствено карактеристична за простор између Дунава и Тисе те опредељена у сам крај 10. и почетак 11. века (Bálint 1991, 123-126, Taf. XXXVI, XLIII/1), док их Е. Гал сврстава у тип $10 \mathrm{~g}$ и везује за прву половину 11. века (Gáll 2013, Т. 315, Т. 331). На основу материјала, чини се да су овакве апликације током 10. века биле израђене од позлаћеног сребра, на шта упућују налази из Еперјеса (Eperjes) (Bálint 1991, 55-59, Taf. V/17-25), Пишпокладња (Püspökladány) (Nepper 1996, fig. 13) или Харт-Фреифелта (Hart-Friefelt) (Lango et all 2016, 297, fig. 13), да би се током 11. века прешло на њихову израду од бронзе. У гробу је такође констатовано и 10 кружних апликација (сл. 6/10), које су идентичне горњим деловима поменутих двоструких апликација. Исти начин украшавања није неуобичајена појава, будући да је констатован и на некрополи у Јазову у гробу 5 (Станојев 1989, 46). У гробу 4 су откривене још две бронзане апликације. Једна од њих је 
кружна, испупчена, украшена концентричним круговима (сл. 6/11), за које одговарајуће аналогије начињене од сребра срећемо у Кикинди (Станојев 1989, кат. бр. 271), односно Трешњевцу, где су откривени примерци били начињени од бронзе, која је у два случаја била позлаћена (Станојев 1989, кат. бр. 632-633). Кружна бронзана апликација украшена троугаоним орнаментима дуж ивице (сл. 6/12) има одговарајуће аналогије у Вршцу, где су апликације биле начињене од сребрног лима (Станојев 1989, кат. бр. 219). Осим тога констатовано је и седам сребрних кружних апликација, од којих је шест било украшено са по два низа неједнаких квадрата (сл. 6/13; сл. 7/Б/1). Истоветни налази констатовани су на некрополи у Јазову у гробу 5 (Станојев 1989, кат. бр. 238). Последња сребрна апликација из гроба 4 украшена је мотивом деветолатичног цвета (сл. 6/14; сл. 7/Б/2). Сличан налаз, са седмолатичним орнаментом, потиче са некрополе у Јазову из гроба 5 (Станојев 1989, кат. бр. 236), док је апликација са украсом од осам латица констатована на локалитету Сабадкиђош (Szabadkigyós) (Bálint 1972, 43).

Бронзана наруквица (сл. 6/15) припада већ помињаном типу 2а, који се везује за прву половину 11. века (Gáll 2013, 677, Т. 311, 330, 333, 334). На простору Војводине овакви налази представљају уобичајени гробни инвентар на раномађарским некрополама (Станојев 1989, 15, 24, 26, 89, 121 , $122,126)$. Два бронзана језичка (сл. 6/17-18) имају одговарајуће аналогије откривене у гробу 6 на локалитету Тисер (Tiszér), где је пронађен сребрни налаз налик нашим, чије је средишњи део био позлаћен (Fodor 1996б, 205-206, figs. 4, 6). Будући да имају сличне орнаменте, можемо претпоставити да наши налази представљају јефтинију варијанту.

На основу гробног инвентара можемо закључити да је у питању сахрана до које је дошло током прве половине 11 века. Одећа преминуле била је богато украшена, али првенствено бронзаним апликацијама, уз спорадичну употребу оних начињених од сребра.

\section{Закључак}

Гробови обрађени у овом раду сведоче о значају који је шири ареал Горњег Брега имао током раносредњовековног периода. На основу предочене грађе може се закључити да најпре долази до формирања позноаварске некрополе, којој припада гроб 1 са локалитета Горњи Брег - Ватрогасна касарна, који је опредељен у средину 8. века. Иако су из Сенте и њене непосредне околине одраније позната три позноаварска налазишта, наша сазнања о овом раздобљу су из различитих разлога ограничена (Бугарски 2014, 542-544, са литературом). У том смислу откривени гроб их у извесној мери допуњује, 
мада и даље није могуће донети коначне закључке о поменутом раздобљу у околини Сенте. Положај металних делова појаса откривених у гробу није уобичајен, будући да се нису налазили у пределу карлице, већ на грудима. Како наш гроб не представља усамљени случај на позноаварским некрополама, скренућемо пажњу да је већ раније изнета претпоставка да појасеве који се не налазе у пределу карлице треба посматрати не као део ношње, већ као гробни прилог (Bugarski et all 2013, 295-296 са наведеном литературом).

Попут других налазишта из периода аварске доминације и локалитет Горњи Брег - Ватрогасна касарна смештен је у контактним зонама плављења, на спојевима различитих геоморфолошких целина (Bugarski 2008, 450-451, Fig. 2). Истоветан начин коришћења простора настављен је и током раномађарског периода, како у Војводини (Radičević and Špehar 2015, Fig. 1; Шпехар и Стругар Бевц 2016, 14), тако и у другим деловима Панонске низије (Takács 2006; Timár and Gábris 2008, 252). Будући да је простор Панонске низије пре хидрорегулационих радова започетих током 18. века био испресецан мочварама и речним токовима (Bugarski 2008, Fig. 1), те као такав подложан плављењу, број позиција на којима се одвијао живот заправо је био ограничен. Упркос томе, у само неколико случајева је констатовано коришћење истих позиција током периода аварске доминације и периода мађарског насељавања у Панонску низију. Одраније познатим налазиштима Банатски Деспотовац, Богојево IV и Сурдук (Шпехар и Стругар Бевц 2016, 104), сада се може прикључити и налазиште Горњи Брег - Ватрогасна касарна. Ипак, треба напоменути да је у сва четири случаја прошло најмање неколико деценија између два хоризонта коришћења, при чему је у нашем случају реч о хијатусу дужем од једног века. Упоредо са сахрањивањем на потесу Ватрогасна касарна, у раздобљу 10-11. века формира се још једна некропола, удаљена око 1,5 км у правцу севера, на супротном крају греде.

Гробови 1 и 2 откривени на потесу Ватрогасна касарна представљају сахране са ратничком опремом, које су биле резервисане за најистакнутије чланове заједнице. Ипак, како остеолошки материјал није очуван, не можемо са сигурношћу тврдити да су сахрањени покојници заиста били коњаници. Због недостатка налаза од племенитог материјала можемо закључити да овде нису сахрањени припадници највишег ранга, већ нешто мање истакнути појединци. Слично се може рећи и за гробове жена. На истакнутији друштвени положај донекле указује сребрна наруквица из гроба 1 са локалитета Горњи брег - Циглана. Гроб 4 са потеса Ватрогасна касарна пак према броју откривених предмета представља најбогатију сахрану, мада треба напоменути да су откривени налази били начињени првенствено од 


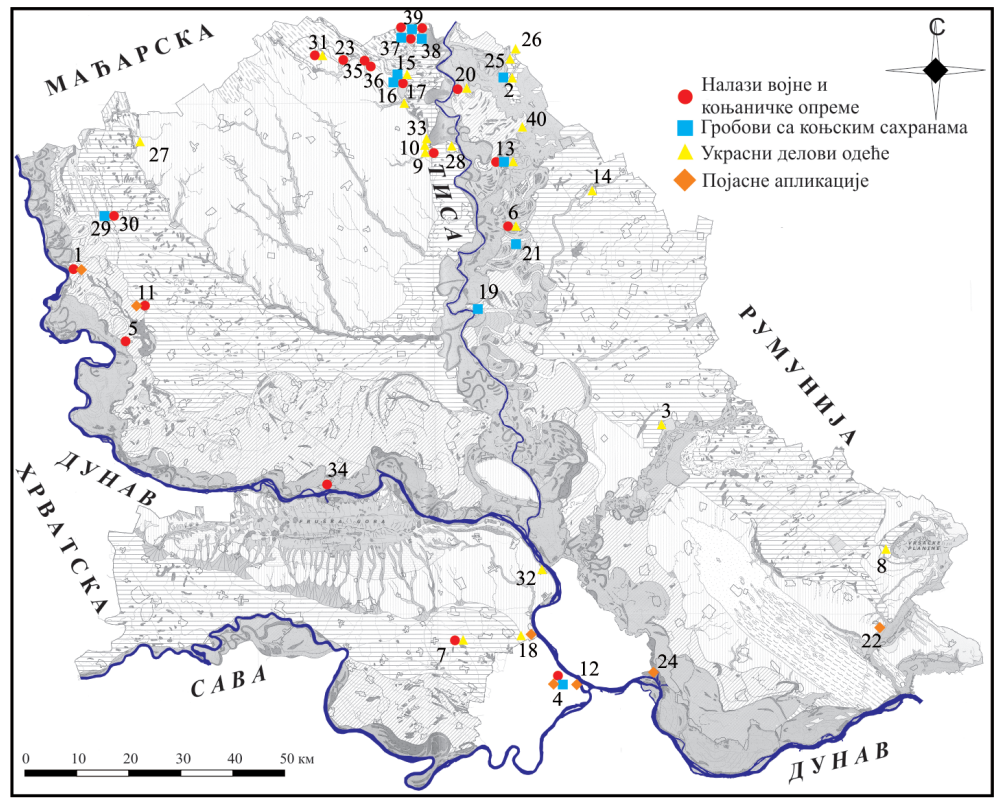

Сл. 8. Карта са положајем локалитета из периода мађарског досељавања у Војводини (нацртао П. Шехар; локалитети су картирани на географској карти преузетој од Кошћали и др. 2006): 1. Апатин - Римски шанци; 2. Банатско Аранђелово 3. Банатски Деспотовац; 4. Батајница; 5. Богојево; 6. Бочар; 7. Војка-Хумка; 8. Вршац; 9. Горњи Брег - Ватрогасна касарна; 10. Горњи Брег - Циглана; 11. Дорослово; 12. Земун; 13. Јазово; 14. Кикинда; 15. Мале пијаце - Мали песак; 16. Мале пијаце - обале Киреша; 17. Мале пијаце - Богарзо; 18. Нови Бановци; 19. Нови Бечеј - Матејски брод; 20. Нови Кнежевац - Посед грофа Талијан; 21. Ново Милошево (Беодра); 22. Орешац; 23. Палић - Жута обала; 24. Панчево; 25. Рабе - Анка Сигет; 26. Рабе- Вашути Орхаз; 27. Станишић - Св. Анте - Машић салаш; 28. Сента; 29. Сомбор; 30. Сомбор - Ранчево; 31. Суботица; 32. Сурдук; 33. Трешњевац; 34. Футог - Режо мајур; 35. Хајдуково - Физфарош; 36. Хајдуково - Чурго/Переш; 37. Хоргош-Хинга; 38. Хоргош-Носа; 39. Хоргош-Камараш; 40. Црна Бара - Пркос

Fig. 8. Map of the sites from the period of the Magyar settlement in Vojvodina (drawn by P. Špehar; sites are mapped on the geographic map taken from Кошћал и др. 2006): 1. Apatin - Rimski šanci; 2. Banatsko Aranđelovo 3. Banatski Despotovac; 4. Batajnica; 5. Bogojevo; 6. Bočar; 7. Vojka-Humka; 8. Vršac; 9. Gornji Breg - Vatrogasna Kasarna; 10. Gornji Breg-Ciglana; 11. Doroslovo; 12. Zemun; 13. Jazovo; 14. Kikinda; 15. Male Pijace - Mali Pesak; 16. Male Pijace - obale Kireša; 17. Male Pijace - Bogarzo; 18. Novi Banovci; 19. Novi Bečej - Matejski Brod; 20. Novi Kneževac - Posed grofa Talijan; 21. Novo Miloševo (Beodra); 22. Orešac; 23. Palić - Žuta Obala; 24. Pančevo; 25. Rabe - Anka Siget; 26. Rabe - Vašuti Orhaz; 27. Stanišić - Sv. Ante - Mašić Salaš; 28. Senta; 29. Sombor; 30. Sombor - Rančevo; 31. Subotica; 32. Surduk; 33. Trešnjevac; 34. Futog - Režo Majur; 35. Hajdukovo - Fizfaroš; 36. Hajdukovo - Čurgo/Pereš; 37. Horgoš-Hinga; 38. Horgoš-Nosa; 39. Horgoš-Kamaraš; 40. Crna Bara - Prkos 
бронзе, док су апликације израђене од сребрног лима, који је само у једном случају био позлаћен, знатно мање заступљене. Ипак, присуство налаза од племенитог материјала, који чине мањи део гробног инвентара, указује на нешто истакнутији положај покојнице. И поред тога, можемо закључити да се ниједна од сахрана из периода мађарског досељавања не може везати за припаднике највишег сталежа.

Оскудни писани извори који сведоче о периоду досељавања Мађара (Gesta Hungarorum: chap. 11; DAI: chap. 40) дали су повод да се у стручној литератури недвосмислено закључи како је данашња Војводина била укључена у састав раномађарске државе по њиховом досељавању у Панонију (Ćirković 1997, 27-37; Sekereš 1997, 138). Овакав закључак је изнет без осврта на археолошки материјал, који указује да се раномађарска налазишта највећим делом налазе са обе стране Тисе, и то у њеном горњем делу тока кроз Војводину, као и дуж Дунава (сл. 8). Такође је уочено да се они најчешће јављају изнад линије Апатин - Нови Бечеј. Стога је изнета претпоставка да густина налазишта, као и количина делова појаса и украса начињених од племенитих метала, указују на разлике између области које су улазиле у састав раномађарске државе и оних које су се само номинално налазиле под управом Мађаpa (Radičević and Špehar 2015, 153; Радичевић и Шпехар 2015, 49; Шпехар и Стругар Бевц 2016, 106-107). Структура налаза откривених на локалитетима у ареалу Горњег Брега, који се налази северно од поменуте линије, иде у прилог овој тврдњи. Раномађарске гробове из Горњег Брега треба посматрати у ширем историјском контексту. Наиме, овај простор је имао очигледно важну улогу у време досељавања Мађара, будући да се око Сенте јавља већи број налазишта из овог периода (сл. $8 / 8,9,26,31)$. Простор у околини Горњег Брега играо је значајну улогу и у каснијем периоду, будући да се свега 1,5 км западно од села налази локалитет Црквено брдо (сл. 1/А), истражен 2019. године, ${ }^{6}$ на коме су откривени остаци насеља из периода $12-15$. века, док је приликом геомагнетних снимања утврђен и положај цркве.

\section{ПИСАНИ ИЗВОРИ}

\section{Gesta Hungarorum}

P. magistri, qui Anonymus dicitur, Gesta Hungarorum, in: Scriptores rerum Hungaricarum tempore ducum regumque stirpis Arpadianae gestarum. Edendo operi praefuit E. Szentpetery Vol. I, ed. Ae. Jakubovich, Budapest 1937, 13-117.

\footnotetext{
${ }^{6}$ Истраживања на траси гасовода организовао је Међуопштински завод за заштиту споменика културе у Суботици, док је теренским истраживањима на поменутом локалитету руководио др Перица Шпехар, ванредни професор.
} 


\section{DAI}

Constantine Porphyrogenitus, De Administrando imperio, ed. Gy. Moravcisk, eng. transl. R.J.H. Jenkins, new, revised edition, Washington 1967.

\section{Taktika}

The Taktika of Leo VI, text, translation and commentary G. Dennis, Revised edition, Washington 2014.

\section{БИБЛИОГРАФИЈА}

Bálint, Cs. (1969). A honfoglalás kori lovastemetkezések néhány kérdése. Móra Ferenc Múzeum Évkönyve 1969/1: 107-114.

Bálint, Cs. (1972). A magyar köznép a X-XI. században: vitázó gondolatok a kor régészeti leleteiröl. Tiszatáj 26/8: 40-49.

Bálint, Cs. (1991). Südungarn im 10. Jahrhundert. Budapest: Akadémiai Kiadó.

Bugarski, I. (2008). The geomorphological matrix as a starting point for determining the position of Avar-time settlements in Pannonia: the example of the Bačka region. Archäologisches Korrespodenzblatt 38/3: 437-455.

Бугарски, И. (2014). Археологија Авара у Србији. Докторска дисертација, Универзитет у Београду.

Bugarski, I., Miladinović-Radmilović, N., Popadić, I., Marjanović, M. (2013). Early Mediaeval Burial at Stubline near Obrenovac: Spatial, Anthropological and Archaeological Analyses of the Southernmost Avar Grave. Acta Archaeologica Carpathica XLVIII: 285-305.

Gáll, E. (2010). Burial customs and the question of $10^{\text {th }}$ century populations in the Transylvanian Basin. Acta Archaeologica Carpathica XLV: 271-314.

Gáll, E. (2013). Az Erdélyi-Medence, a Partium és a Bánság 10-11. századi temetői szórvány- és kincsleletei $1-2$. Szeged: OTKA.

Gáll, E. (2015). An attempt to classify the stirrups dating from the 10th century and the first quarter of the 11th century in the Transylvanian Basin, the Crișana/Partium and the Banat with an outlook to the Carpathian Basin, in Warriors, weapons, and harness from the $5^{\text {th }}-10^{\text {th }}$ centuries in the Carpathian Basin, ed. C. Cosma, 355-406. Cluj-Napoca: Mega Publishing House.

Garam, A. (1987). Der awarische Fundstoff im Karpatenbecken und seine zeitliche Gliederung, in Die Völker Südosteuropas im 6. Bis 8. Jahrhundert, Hrsg. B. Hänsel, 191-202. Berlin: Südosteuropa-Gesselschaft München/Seminar für Ur- und Frühgeschichte der Freien Universität Berlin.

Giesler, J. (1981) Untersuchungen zur Chronologie der Bjelo Brdo Kultur. Ein Beitrag zur Archäologie des 10. und 11. Jahrhunderts im Karpatenbecken. Prähistorische Zeitschrift 56/1: 4-167.

Demo, Ž. (1983). Bjelobrdski privesci u Jugoslaviji (u povodu nalaza s lokaliteta Đelekovec - Gornji Batijan I). Podravski zbornik 83: 271-301. 
Demo, Ž. (2009). An Early Medieval Cemetery of the Bijelo Brdo Culture: Vukovar - Lijeva Bara (10th - 11th Centuries). Zagreb: Arheološki muzej.

Ђорђевић, В. (2010). Археолочка налазишта и налази средњовековног периода на територији југозападног Баната. Магистарски рад, Универзитет у Београду.

Zábojník, J. (1991). Seriation von Gürtelbeschlaggarnituren aus dem Gebeit der Slowakei und Österreichs (Beitrag zur Chronologie der Zeit des awarischen Kaganats), in K problematike osídlenia Stredodunajskej oblasti vo včasnom stredoveku, ed. Z. Čilinská, 219-323. Nitra: Archeologický ústav Slovenskej akadémie vied.

Јовановић, В. (1996). Прапорци у јужнословенским некрополама, прилог проучавању амулета. Рад музеја Војводине 37-38: 83-112.

Јокић, И. (2004). Општина Сента - Географска монографија, Нови Сад: Универзитет у Новом Саду, Природно-математички факултет, Департман за географију, туризам и хотелијерство.

Кошћал, М., Менковић, Љ., Мијатович, М. и Кнежевић, М. (2005). Геоморфолошка карта аутономне покрајине Војводине, 1:200.000. Београд: Геозавод-Гемини.

Kovács, L. (1986). Über einige Steigbügeltypen der Landnahmezeit. Acta Archaeologica Academiae Scientiarum Hungaricae XXXVIII/1-2: 195-225.

Kovács, L. (1992). A Móra Ferenc Múzeum néhány régi, 10-11. századi leletanyagáról: Oroszlámos, Horgos, Majdán, Rábé, (Csóka). A Móra Ferenc Múzeum Évkönyve 1992/1: 37-74.

Kovács, L. (1994). Das früharpadenzeitliche Gräberfeld von Szabolcs, Budapest: Academia scientarium Hungarica.

Kürti, B. (1997). A honfoglalás dél-magyarországi szemszögből, u 1100 godina doseljenja Mađara u Vojvodinu/A honfoglalás 1100 éve és a Vajdasaág, ur. Đ. Bordaš et al., 127-132. Beograd-Ùjvidék: Zavod za udžbenike i nastavna sredstva-Forum.

Langó, P., Kustár, R., Köhler, K., Aranka, Cs. (2016). A Study of the Tenth-Century Cemetery at Harta-Freifelt. Antaeus 34: 389-416.

Nepper, I. (1996). Püspökladány-Eperjesvölgzy, in The Ancient Hungarians. Exhibition Catalogue, Hungarian National Museum Budapest, March 16-December 31, 1996, ed. I. Fodor, 245-256. Budapest: Hungarian National Museum.

Radičević, D. and Špehar, P. (2015). Some remarks on Hungarian Conquest Period Finds in Vojvodina. Acta Archaeologica Carpathica XLIX: 137-162.

Радичевић, Д., Шпехар, П. (2015). Порфирогенитови међаши на Истру и старомађарски археолошки налази у Војводини. Зборник радова Византолошког институma LII: 43-55.

Révész, L. (1987). Lyraförmige Schnallen in dem Karpatenbecken. Acta Archaeologica Academiae Scientiarium Hungaricae XXXIX: 257-285.

Réveész, L. (1996). Kenézlö-Fazekaszug cemeteries I-II, in The Ancient Hungarians. Exhibition Catalogue, Hungarian National Museum Budapest, March 16-December 31, 1996, ed. I. Fodor, 150-157. Budapest: Hungarian National Museum. 
Révész, L. and Nepper, M. I. (1996). The archaeological heritage of the ancient Hungarians, in: The Ancient Hungarians. Exhibition Catalogue, Hungarian National Museum Budapest, March 16 - December 31, 1996, ed. I. Fodor, 37-56. Budapest: Hungarian National Museum.

Szekeres, L. (1971). Zenta és környéke törtenete a régészeti leletek fényében, Građa za monografiju Sente 18. Senta: Udarnik.

Sekereš, L. (1997). Pregled stanja istraživanja o dobu dolaska Mađara u Karpatski basen i Vojvodinu, 1100 godina doseljenja Mađara u Vojvodinu / A honfoglalás 1100 éve és a Vajdasaág, ur. Đ. Bordaš et al., 137-142 Beograd-Ùjvidék: Zavod za udžbenike i nastavna sredstva - Forum.

Szilágyi. K. (1995). The Beads of tenth-to twelfth century Hungary. Beads. Journal of the Society of Bead Researchers: 65-95.

Szilágyi, K., Nagy-Balogh, J., Solymos K.G. (1995) Similar Beads of Type 60 from Ninth-Century Magna Hungaria and Tenth-Century Hungary, in Glass Beads: Cultural History, Technology, Experiment and Analogy, eds. M. Rasmussen, U.L. Hansen, U. Näsman, 83-89. Lejre: Historical-Archaeological Experimental Centre.

Станојев, Н. (1989). Некрополе $X-X V$ века у Војводини. Нови Сад: Археолошко друштво Војводине.

Takács, M. (2006). Siedlungsgeschichtliche Auswertung, in Das frühungarische Reitergrab von Gnadendorf (Niederösterreich), Hrsg. F. Daim, E. Lauermann, 211-252. Mainz: Römisch-Germanischen Zentralmuseums.

Timár, G. and Gábris, G. (2008). Estimation of water conductivity of the natural flood channels on the Tisza flood-plain, the Great Hungarian Plain. Geomorphology 98: 250261.

Türk, A. (2014). Towards a Classification of Grave Types and Burial Rites in the $10^{\text {th }}$ $11^{\text {th }}$ Century Carpathian Basin, in Avars, Bulgars and Magyars on the Middle and Lower Danube, Proceedings of the Bulgarian-Hungarian Meeting May 27-28 2009, eds. L. Doncheva-Petkova, C. Balogh, A. Türk, 37-155. Sofiya-Piliscsaba: Archaeolingua.

Ćirković, S. (1997). Međaši duž Istra. O južnoj granici Mađara u X veku, u 1100 godina doseljenja Mađara u Vojvodinu/A honfoglalás 1100 éve és a Vajdasaág, ur. Đ. Bordaš et al., 27-37. Beograd-Ùjvidék: Zavod za udžbenike i nastavna sredstva-Forum.

Fodor, I. (1996a). Rakamaz-Strázsadomb, in The Ancient Hungarians. Exhibition Catalogue, Hungarian National Museum Budapest, March 16 - December 31, 1996, ed. I. Fodor, 110-119. Budapest: Hungarian National Museum.

Fodor, I. (1996b). Tuszér, in The Ancient Hungarians. Exhibition Catalogue, Hungarian National Museum Budapest, March 16 - December 31, 1996, ed. I. Fodor, 204-206. Budapest: Hungarian National Museum.

Шпехар, П. и Стругар Бевц, Н. (2016). Батајница - Велика хумка. Раномађарска некропола. Београд: Музеј града Београда. 


\title{
Perica Špehar
}

University in Belgrade, Faculty of Philosophy - Department of Archaeology, Belgrade

\author{
Raško Ramadanski \\ City Museum of Bečej, Bečej
}

\section{EARLY MEDIEVAL FINDS FROM GORNJI BREG NEAR SENTA}

Keywords: Southern Pannonia, necropoles, Early Medieval period, Late Avar period, Early Magyar period

In the archaeological collection of the City Museum in Senta, several dozens of early medieval archaeological finds are kept that were not adequately published but only briefly mentioned in previous scholarly literature. Based on the insight in scarce field documentation and books of inventory it is determined that the said finds were discovered in the mid- $20^{\text {th }}$ century in the village of Gornji Breg. They originate from two sites, where three necropoles were discovered.

On the site Ciglana, $1.5 \mathrm{~km}$ north of the Gornji Breg, a grave was discovered in 1958, dated into the period of the Magyar settlement in the Pannonian Plain. It belonged to a female person of a high status, as suggested by a silver bracelet, and is dated into the first half of the $10^{\text {th }}$ century according to the grave inventory.

The second site was discovered in 1963, during the fieldwork in the yard of the fire-fighters quarters - Vatrogasna Kasarna and neighbouring house in Gornji Breg. During the small-scale archaeological excavations, five graves were detected. One of them belongs to the Late Avar period and is dated into the mid- $8^{\text {th }}$ century according to the bronze parts of the warrior belt. Four remaining graves, a few tens of meters away from the Late Avar funeral, can be dated into the period of the Magyar settling, i.e. into the second half of the $10^{\text {th }}$ and the first half of the $11^{\text {th }}$ century. Graves nos. 1 and 2 from the Early Magyar necropolis are warriors' burials. According to the discovered finds, the persons buried here were not members of the highest social rank, but somewhat less prominent individuals. Similar can be said for the remaining two graves, in which female persons were buried, although several silver clothes' ornaments testify of the somewhat higher social position of a person buried in Grave no. 4 . This is the richest burial on the site, although it should be mentioned that all clothes' ornaments were made of bronze. 
The structure of the finds discovered in Gornji Breg suggests that this location was used during the period of Avar domination and once again during the period of the Magyar settlement, one century later. 